\title{
Redesign of a water quantity, quality, and sediment-monitoring network in a tropical region
}

\author{
Rediseño de una red de monitoreo de sedimentos, calidad y cantidad de agua en una región \\ tropical
}

\section{Jorge Julián Vélez-Upegui (iD ${ }^{1 *}$, Adela Londoño-Carvajal (iD ${ }^{2}$, María Valentina Solórzano-Gómez ${ }^{1}$, Jaime Ignacio Vélez-Upegui (iD ${ }^{3}$, Verónica Botero-Fernández (iD ${ }^{3}$}

${ }^{1}$ Departamento de Ingeniería Civil, Universidad Nacional de Colombia Sede Manizales, Campus Palogrande. C. P. 170004. Cra. 27 \#64-60. Manizales, Colombia.

${ }^{2}$ Departamento de Ingeniería Química, Universidad Nacional de Colombia Sede Manizales, Campus Palogrande, C. P. 170004. Cra. 27

\#64-60. Manizales, Colombia

${ }^{3}$ Departamento de Geociencias y Medio Ambiente, Facultad de Minas, Universidad Nacional de Colombia Sede Medellín. C. P. 050034. Av. 80 \#65-223. Medellín, Colombia

\section{CITE THIS ARTICLE AS:}

\section{J. J. Vélez, A. Londoño, M. V.}

Solórzano, J. I. Vélez and V.

Botero. "Redesign of a water

quantity, quality, and

sediment-monitoring network

in a tropical region", Revista

Facultad de Ingeniería

Universidad de Antioquia, no.

96, pp. 64-77, Jul-Sep 2020.

[Online]. Available: https:

//www.doi.org/10.17533/

udea.redin. 20191150

\section{ARTICLE INFO:}

Received: May 28, 2019 Accepted: November 08, 2019

Available online: November

08, 2019

\section{KEYWORDS:}

Hydrological networks; surface hydrology; environment; macro-location: GIS

Redes de monitoreo hidrológico; hidrología superficial; medio ambiente; macro-localización; SIG
ABSTRACT: The CORNARE region, located in Antioquia (Colombia), required a redesign of its water quantity, quality, and sediment-monitoring network, in order to collect convincing data to help decision-makers to respond to different technical and environmental issues. This paper proposes a methodology which is based on secondary information and which employs Geographical Information System -GIS- tools and knowledge of the region, given that historical data are unavailable in most of the region. Although the main methodology, which applied physical, anthropic, and economic factors was the same for all networks, specific strategies were used for water quantity, quality, and sediment networks in the region. These used expert criteria and weight distance methods. The results were satisfactory. Macro-location was implemented for the sites monitored in the CORNARE region, and this indicated that the proposed methodology was adequate for tropical Andean watersheds, where historical data were insufficient and did not permit the use of more complex techniques. This methodology integrates water quantity, water quality and sediment in an integrated hydrological monitoring network.

RESUMEN: La región de CORNARE, ubicada en Antioquia (Colombia), requirió un rediseño de su red de monitoreo de sedimentos, cantidad y calidad de agua, con el fin de recopilar datos convincentes para ayudar a los tomadores de decisiones a responder a diferentes problemas técnicos y ambientales. Este artículo propone una metodología que se basa en información secundaria y que emplea herramientas de Sistemas de Información Geográfica SIG y el conocimiento de la región, dado que los datos temporales de las series históricas no están disponibles en la mayor parte de la región. Si bien la metodología principal, que aplica factores físicos, antrópicos y económicos, fue la misma para todas las redes, se utilizaron estrategias específicas para las redes de monitoreo de cantidad de agua, calidad de sedimentos en la región. Estos factores fueron seleccionados de acuerdo con criterios de expertos y métodos de distancia y de peso. Los resultados obtenidos fueron satisfactorios. Se implementó la macro localización para los sitios de monitoreo en la región de CORNARE, lo que indicó que la metodología propuesta es adecuada para las cuencas hidrográficas andinas tropicales, donde los datos temporales históricos son insuficientes y no permitía el uso de técnicas más complejas. Esta metodología integra la redes de monitoreo de cantidad de agua, de calidad del agua y de los sedimentos en una red integrada de monitoreo hidrológico.

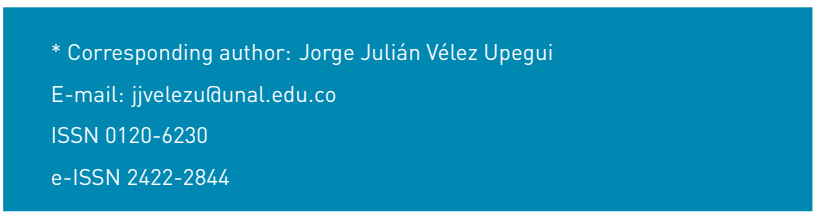




\section{Introduction}

The environmental authority, Corporación Autónoma Regional de las cuencas de los ríos Negro y Nare, abbreviated CORNARE, should consider updates to its water monitoring networks along the main rivers, based on the existing monitoring network and available information, in order to tackle water resource planning and management challenges. Its current monitoring network is insufficient to properly meet regional quantity, quality, and sediment requirements. This document proposes a redesign of its current monitoring network, and seeks to improve the spatial distribution of monitoring station macro-locations, so as to capture data and respond to different water resource planning instruments.

Anthropic activities and the ways in which humans use water resources and the territories adjacent to the rivers affect the quantity and quality of consumption water, risk management, entertaining opportunities, and the health and diversity of aquatic and riparian ecosystems, because all life depends on water and all of us are citizens of the basin [1].

The most recent review of monitoring site macro-locations for river water quality design criteria is shown [2], where the different strategies, based on statistical methods, including correlation, regression, principal component analysis, entropy, and multivariate analysis, are highlighted. These can be practical for water quality networks. However, the use of Geographical Information System (GIS) maps and genetic algorithms were introduced by [3], as to minimize critical issues related to the subjective or intuitive design of water-quality monitoring networks. [2, 4] mention that water quality parameters, monitoring frequencies, and monitoring station locations should be justified in terms of costs, precision, reliability, and monitoring objectives.

[5] performed an intensive review of entropy applications for water-monitoring network design, sediment, precipitation, groundwater, soil moisture, quantity, and quality networks, but their approach requires historical information for proper application of the entropy concept. Said authors mention that further research is required in terms of spatial and temporal data scaling for entropy calculation. Many new methods and optimization techniques were reviewed, but few examples were found in the literature. Additional research is required to provide guidance on the proper length of data for water-monitoring network design, sampling frequency, and the spatial scale at which information should be measured for various monitoring network applications.

In the absence of historical information, simple procedures based on secondary information available from GIS, limited historical information that is normally available from the many Colombian environmental authorities, and GIS tools are strategic and indispensable in water-quality network design, operation, and optimization [6].

Another relevant contribution was presented by [7], in which the objectives of the monitoring networks are the main characteristic to be included, their proposal is based on an existing network, redundancies, gaps in the spatial coverage, and physical constraints for new monitoring sites.

[8] focused on the overall monitoring program, where the proposed analysis utilized water quality modeling to determine the locations of sampling sites. This was done so as to minimize contaminant detection time for the river network, while simultaneously achieving maximum monitoring system performance reliability through the use of genetic algorithms and Pareto Analysis optimization procedures. This methodology requires previous data and parameters in order to feed a water quality model. The Environmental Protection Agency [9] specifies that monitoring programs must establish water quality standards in accordance with monitoring objectives for the determination of water quality and trends. Thus, compromised water, as well as the causes and sources of water quality problems may be identified. However, the present investigation does not focus on monitoring programs, but rather on monitoring network macro-locations.

[10] highlighted that the establishment of a proper network to monitor water quantity and quality provides the basis for watershed characterization, as well as the impacts of development, including activities such as mining on and around the project site. The transparent, beneficial data collected by these networks can be used for purposes of regulatory compliance, risk limitation, infrastructure design, ISO 14001 certification, assessment of impacts on downstream aquatic ecosystems, and determination of the efficiency of mining processes. Furthermore, it may be employed to determine whether mining activities affect water or food security in local communities. Water quantity recommendations are provided by the World Meteorological Organization [11].

Sediment transport is the general term used for the transport of the material (clay, silt, sand, gravel, and boulders) found in rivers and streams. Said material is called sediment load, which is studied by way of suspended and bed load. A distinction is made between bed load and suspended load: bed load is characterized by grains rolling, sliding and jumping along the river bed, while suspended load refers to smaller sediment grains 
suspended by turbulence [12]. Both of these must be monitored in tropical basins via different methods [13]. Recommendations for sediment monitoring are detailed in $[14-16]$.

The Environmental Protection Agency [17] views watersheds as non-static, integrated systems which can be understood through health assessments, introducing a health index, which captures the interacting dynamics of their essential ecological attributes. These include expected future changes, such as land and water use alterations, as well as vulnerability to climate change and population growth.

Monitoring must be implemented for quantity, quality, and sediment, as quantity and sediment are important factors in the interpretation of water quality and biological community data. These biome characteristics indicate stream water quality. Organisms such as algae, bacteria, fungi, invertebrates, protozoa, and fish have a widespread range of sensitivities to physical and chemical fluctuations in their habitat. For instance, high concentrations of nitrogen and phosphorus correlate with growth of algae populations. The abundance of worms and mosquitoes tolerant of pollution, or a community of sparse fish, or one that is composed of non-native species are bio-indicators of poor water quality. [1].

Beginning in 2004, the European water framework directive has formulated the concept of ecological quality status (EcoQ) for the assessment of water mass quality. The EcoQ is an integrated index, which is based upon the status of biological, hydro-morphological, and physicochemical quality elements. Biological elements are of special importance in said index. Physicochemical elements include both general variables (such as dissolved oxygen, nutrients, etc.) and specific pollutants. The former correspond to variables measured directly in the water $[18,19]$ concluded that sediment monitoring programs should address the basic physicochemical properties of sediments (grain size distribution, organic carbon content, etc.), as well as the geomorphological processes within each river system.

Biological communities also expose the ecologic condition of a watershed, and must thus be included in the quality monitoring strategy. The hydrology and stream habitat along the river can be modified by physical basin processes, such as deforestation and fires. The biological communities can also be affected and quickly degrade long before nutrients and other contaminants reach high levels. The potential effects of pollutants on aquatic habitats and drinking-water supplies depend basically on the amount of water. More flow rates of water generally means that rivers and streams transport a greater quantity of pollutants and sediment, in part because of overland runoff. This phenomena is critical if occurs during the aquatic plants and animals critical life cycle phases, particularly when waters carrying high loads reach gulfs and bays [1].

Monitoring programs occur at different time scales and in different environmental sites. Sampling and analysis methods, however, are uniform, and monitoring must be performed at places which are representative of basins, such that comprehensive assessments may be made on larger, even regional, scales. The data collected can help to answer a variety of technical and environmental questions. In this way, the multi-scale approach helps to decide whether certain types of water-quality concerns are isolated or prevalent, and allows rivers and streams to be compared with other places.

Physical features, such as topography, geology, climate, and vegetation define watersheds, which are territories that receive rainfall and runoff to specific surface-water bodies, which may include reservoirs, lakes, streams, bays, or oceans. Both natural and human-induced conditions within the basin are reflected in the water quantity, quality, and sediment transport, and as such, must be monitored [1]. Thus, the present study focused on physical and anthropic characteristics, in an effort to propose a methodology for the redesign of monitoring networks.

Water-quality management and policies must be implemented inside the basin boundaries, rather than being developed in terms of administrative boundaries, such as municipalities, departments or states. While many regional environmental agencies focus on the larger river watersheds, local communities and citizens are frequently worried with the smaller basins present in their areas. Because the less significant watersheds are "nested" within the larger river networks, and because major basins cross jurisdictions, successful water resources management involves that everyone work together-citizens and water-managers, as well as local, regional, and national environmental authorities and stakeholders [1].

The intention of this publication is to update surface-water quantity, quality, and sediment monitoring networks in tropical watersheds, by way of restructuring or redesigns to better understand their complexity and diversity. The regulation of surface streamflow quantity, quality, and sediment, throughout regions, can help decision-makers to learn more about water and ecosystem resources, and improve the adaptive capacity of different water management problems, such as climate change. Effective monitoring must be systematic, long term, and include, 


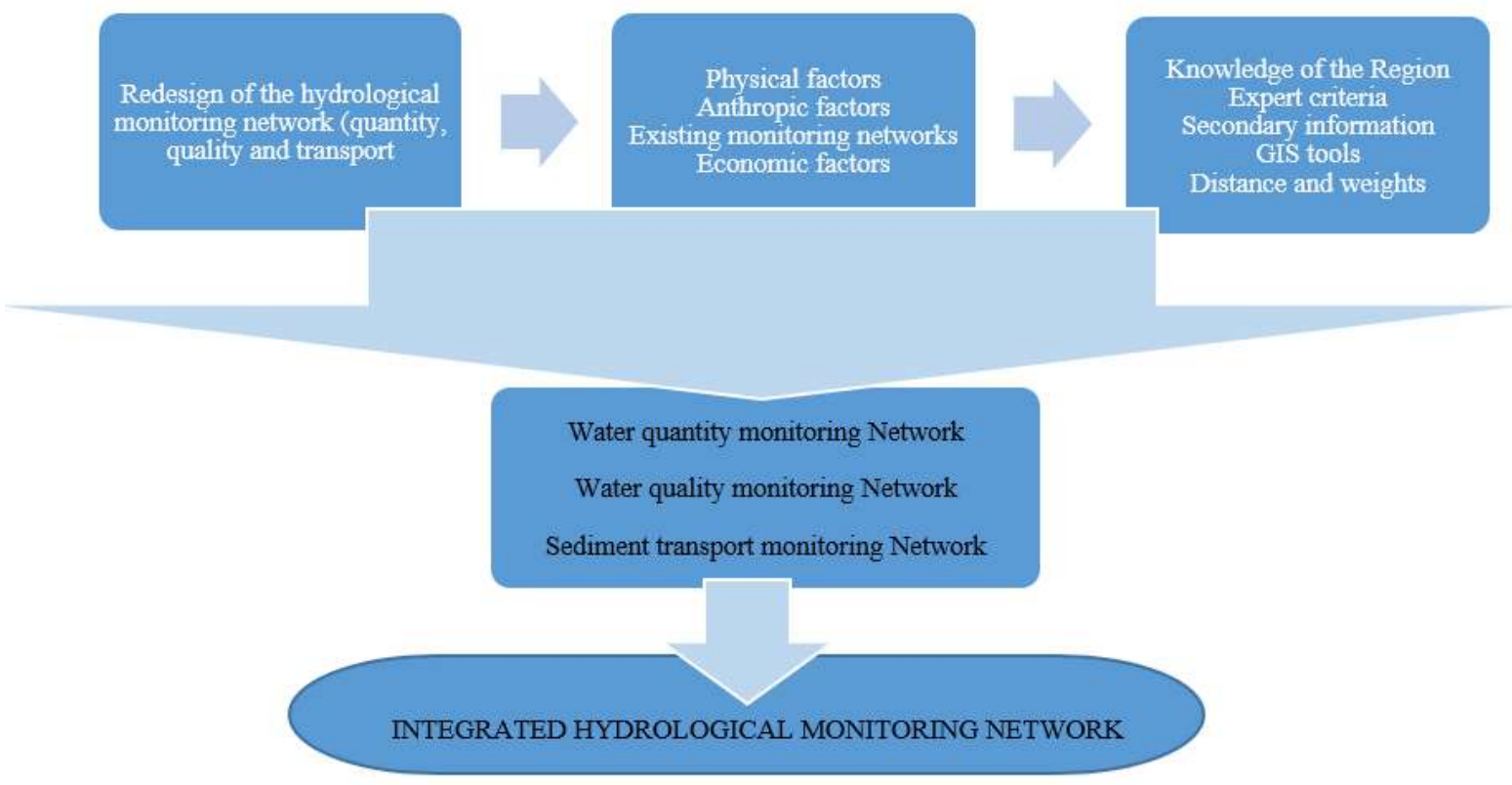

Figure 1 General methodology proposed for the redesign of the monitoring network (quantity, quality, and sediments)

sediment, quantity and biochemical measurements. That said, this publication focuses exclusively on the macro-location of monitoring stations in quantity, quality, and sediment networks, in tropical areas with lack of spatial-temporal data.

\section{Materials and methods}

The redesign of any national monitoring network should be based on the objectives of the National Policy (Colombia) for the Integral Management of Hydrological Resources [20], whose main goal is "To guarantee the sustainability of the hydric resource, through management and efficient and effective use, articulated with land management and the conservation of ecosystems that regulate water supply, as water is a factor in both economic development and social welfare, and implementing equitable and inclusive participation processes". However, the specific objectives for the present study are based on resource and infrastructure planning, risk mitigation, operation and management, early warning systems, compliance, and audits. Said objectives aim to strengthen an adequate surface water monitoring network, which encompasses water supply, water quality, risk management, and the institutional governance of environmental agencies, or in this case, CORNARE.

Based on the competence of CORNARE's employees, as well as that of academics from various universities with experts in water quantity, quality, and sediment transport, expert criteria for the water monitoring redesign were defined. These experts reviewed the secondary available data in the region, as related to physical, anthropogenic, economic aspects, and existing monitoring sites, and were able to propose the best available information as criteria for the natural river monitoring network redesign proposal.

The proposal for the optimal redesign or structuring of the quantity, quality, and sediment monitoring network proposed, emphasizing that, initially, the general methodology of easy adaptation to the different specific cases is proposed below, as shown in Figure 1, where physical secondary information is available.

The weight-distance method is a type of interpolation with a well-known scattered set of points. Values are estimated with a weighted average of the values available at the known points [21].

The first phase of the methodology serves to understand the CORNARE region, and is based on the knowledge of the region provided by different experts and criteria, which analyze different points of view, such as physical and anthropic characteristics and existing networks, all of this information is available and supported by maps, which are previously processed using GIS tools. The overlaying of different maps suggests monitoring points, in accordance with different criteria for physical and anthropic characteristics. Next, a comparison with the existing network is performed, and the network is complemented. Three main monitoring networks are obtained, one for water quantity, a second one for water quality, and a third for sediment transport. Following these analyses, three networks are merged, and this final overlaying yields the macro-location of the required 

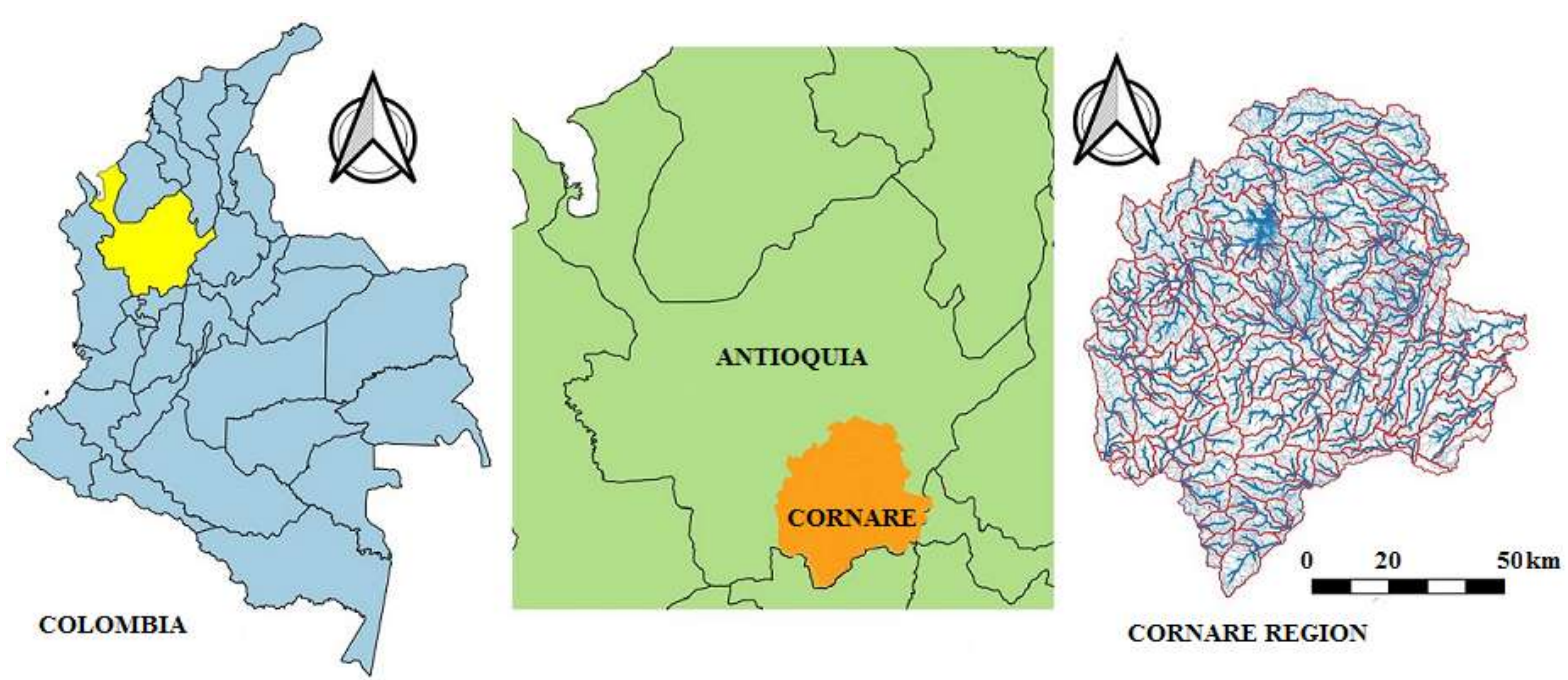

Figure 2 General location of CORNARE study area for the hydrological monitoring network redesign (quantity, quality, and sediments). Source: Adapted from http://www.cornare.gov.co/corporacion/division-socio-ambiental/localizacion-regional

stations. The stations of priority are those sites where all components are present, in accordance with the concept of distance proposed by [22].

\subsection{Understanding the CORNARE region}

The study area consists of twenty-six (26) municipalities in the south-eastern region of Antioquia (Colombia) as shown in Figure 2, with an approximate area of $8,276 \mathrm{~km}^{2}$ which corresponds to $13 \%$ of the department of Antioquia and $0.7 \%$ of Colombia. The CORNARE region is distributed into sub-regions, such as the San Nicolás Valley, totaling $1,766 \mathrm{~km}^{2}\left(314 \mathrm{~km}^{2}\right.$ urban and $1,452 \mathrm{~km}^{2}$ rural), forests, with $1,627 \mathrm{~km}^{2}$ (22 $\mathrm{km}^{2}$ urban and $1,605 \mathrm{~km}^{2}$ rural), water bodies, with an extension of $1,465 \mathrm{~km}^{2}$ (urban $46 \mathrm{~km}^{2}$ and rural $\left.1,419 \mathrm{~km}^{2}\right)$, Porce-Nus, with an area corresponding to $1,017 \mathrm{~km}^{2}$ (urban $72 \mathrm{~km}^{2}$ and rural $945 \mathrm{~km}^{2}$ ), and Páramo, in an extension of $2,402 \mathrm{~km}^{2}$ lurban $66 \mathrm{~km}^{2}$ and rural 2,336 $\mathrm{km}^{2}$ ), [22].

The main geological feature in the area is a formation from the end of the Mesozoic era, the Antioquia and Sonsón Batholiths, lquartz diorite, granodiorite, and quartz monzonite) which was created following a period of intense tectonic activity. An enormous fracture is associated with said batholiths, the Romeral fault, which runs along the western flank of the Central Andes. This unmasks structural drainage control difficulties with eroding surfaces, where residual soils and gravitational deposits have been observed. Hydrogeological recharge areas range from the San Nicolás Valley to the reservoir area to eroded surfaces, where the general flow direction is West-East. The fault zones are preferential hydraulic conduits, whose conductivity in the fault zones may be in the same order of magnitude as that of sands (POMCA of the Nare River https: //www . cornare.gov.co/POMCAS/PRESENTACIONES_ TALLERES_DIAGNOSTICO-PROSPECTIVA/RIO_NARE/ RESULTADOS_FASE_DIAGNOSTICO_RIO_NARE.pdf). The CORNARE region has great hydroelectric potential, but its use depends on the hydrological and environmental behavior of the upper basin (Rio Negro Basin). The Nare River basin has been managed by CORNARE in four (4) zones, as follows: the Río Negro Basin lupstream of the Peñol-Guatapé Reservoir), Nare River Basin (downstream of the reservoir], Samaná-Norte River Basin, and the Nús River Basin [23].

This area has an average monthly temperature of $19^{\circ} \mathrm{C}$, bimodal rainfall regime associated with the Intertropical Confluence Zone ITCZ [24, 25], average annual rainfall of $3,137 \mathrm{~mm}$, which is of great hydrological importance, and a mean hydric yield of $61.18 \mathrm{~L} / \mathrm{s} / \mathrm{km}^{2}$ [26]. This region is also strongly influenced by El Niño South Oscillation, ENSO [27].

Different indexes have been applied to the region, and these were included in the present study. The most relevant of these were: water retention and regulation index, aridity index, surface-water use index, morphometric indices, and vulnerability indices, due to water stress and torrential events. All of these data were provided by the Colombian National Water Study [23, 26]. The region is widely variable in altitude, climate, geology, land use, and population density, which makes this area a complex region to determine ideal monitoring network station locations.

The next step was to propose a methodology for the 
Table 1 Information required for the proposed redesign methodology of the water-quantity monitoring network

\begin{tabular}{|c|c|c|c|}
\hline Physical factors & Anthropic factors & $\begin{array}{c}\text { Existing } \\
\text { monitoring } \\
\text { network }\end{array}$ & Economic factors \\
\hline $\begin{array}{c}\text { Hydric yield } \\
\text { Drainage network } \\
\text { Annual precipitation } \\
\text { Horton-Strahler order } \\
\text { Drainage Density } \\
\text { Slope and stream geomorphology } \\
\text { Water regulation index } \\
\text { Vulnerability indices } \\
\text { Aridity index }\end{array}$ & $\begin{array}{c}\text { Municipalities } \\
\text { Reservoirs } \\
\text { Water supply Micro-basins } \\
\text { Agricultural Zones } \\
\text { Security } \\
\text { Derivations and } \\
\text { pumping stations } \\
\text { Accessibility } \\
\text { Water use index }\end{array}$ & $\begin{array}{l}\text { Climatic stations } \\
\text { Limnometric } \\
\text { stations } \\
\text { Limnigraphic } \\
\text { stations }\end{array}$ & $\begin{array}{l}\text { According to the availability } \\
\text { of the EA, priority levels } \\
\text { were established for the } \\
\text { installation of the new } \\
\text { stations that make up } \\
\text { the network, following } \\
\text { accessibility, security, } \\
\text { and land use. } \\
\text { Priority will always } \\
\text { be given to the } \\
\text { maintenance cost } \\
\text { of the network. }\end{array}$ \\
\hline
\end{tabular}

Source: Adapted from [23].

Table 2 Proposed information required for the proposed redesign methodology for the water-quality and hydro-biological monitoring network

\begin{tabular}{|c|c|c|c|}
\hline Physical factors & Anthropic factors & $\begin{array}{c}\text { Existing } \\
\text { monitoring } \\
\text { network }\end{array}$ & Economic factors \\
\hline $\begin{array}{c}\text { Drainage network } \\
\text { Hydric yield } \\
\text { Horton-Strahler order } \\
\text { Drainage density } \\
\text { Slope and Geomorphology } \\
\text { reach } \\
\text { Water regulation index } \\
\text { Vulnerability indexes } \\
\text { Aridity index }\end{array}$ & $\begin{array}{c}\text { Municipalities } \\
\text { Reservoirs } \\
\text { Location of water treatment } \\
\text { plants (including wastewater). } \\
\text { Industrial, agricultural and } \\
\text { domestic discharges, water } \\
\text { supply, micro-basins, } \\
\text { accessibility, security, } \\
\text { derivations, and pumping } \\
\text { stations. } \\
\text { Water use index }\end{array}$ & $\begin{array}{l}\text { Two water quality } \\
\text { monitoring stations } \\
\text { suggested by the } \\
\text { IDEAM (Ministry } \\
\text { of the Environment) }\end{array}$ & $\begin{array}{l}\text { According to the budget } \\
\text { availability of the EA, } \\
\text { priority levels will be } \\
\text { established for the } \\
\text { installation of new } \\
\text { stations that make up } \\
\text { the network following: } \\
\text { accessibility, security, } \\
\text { and land use. } \\
\text { Priority will be always } \\
\text { given to the maintenance } \\
\text { cost of the network. }\end{array}$ \\
\hline
\end{tabular}

Source: Adapted from [23].

redesign of the most extensive network in the CORNARE region, hydrometric or water quantity networks, followed by the redesign of a network of physical-chemical monitoring stations, to include hydro-biological water quality monitoring. Thereafter, the sediment monitoring network was to be redesigned. All of these were to be redesigned separately, and subsequently governed by a monitoring protocol, so as to finally integrate all of the information collected into a single network for the CORNARE region.

\subsection{A monitoring protocol}

Monitoring protocols are necessary to ensure that waters may continue to support the diversity of ways in which these resources are used and to allow for tracking of whether protection and restoration measures are adequate for each stream or river.

The main methodology includes GIS manipulation of secondary information available on maps to obtain point of interest maps generated for the region, by way of expert criteria and weight distance procedures. The processed maps used for each monitoring network are shown in Tables 1 - 3, as are point of interest maps for water quantity, quality, and hydro-biological, and sediment 
Table 3 Proposed information required for the proposed redesign methodology of the sediment-monitoring network

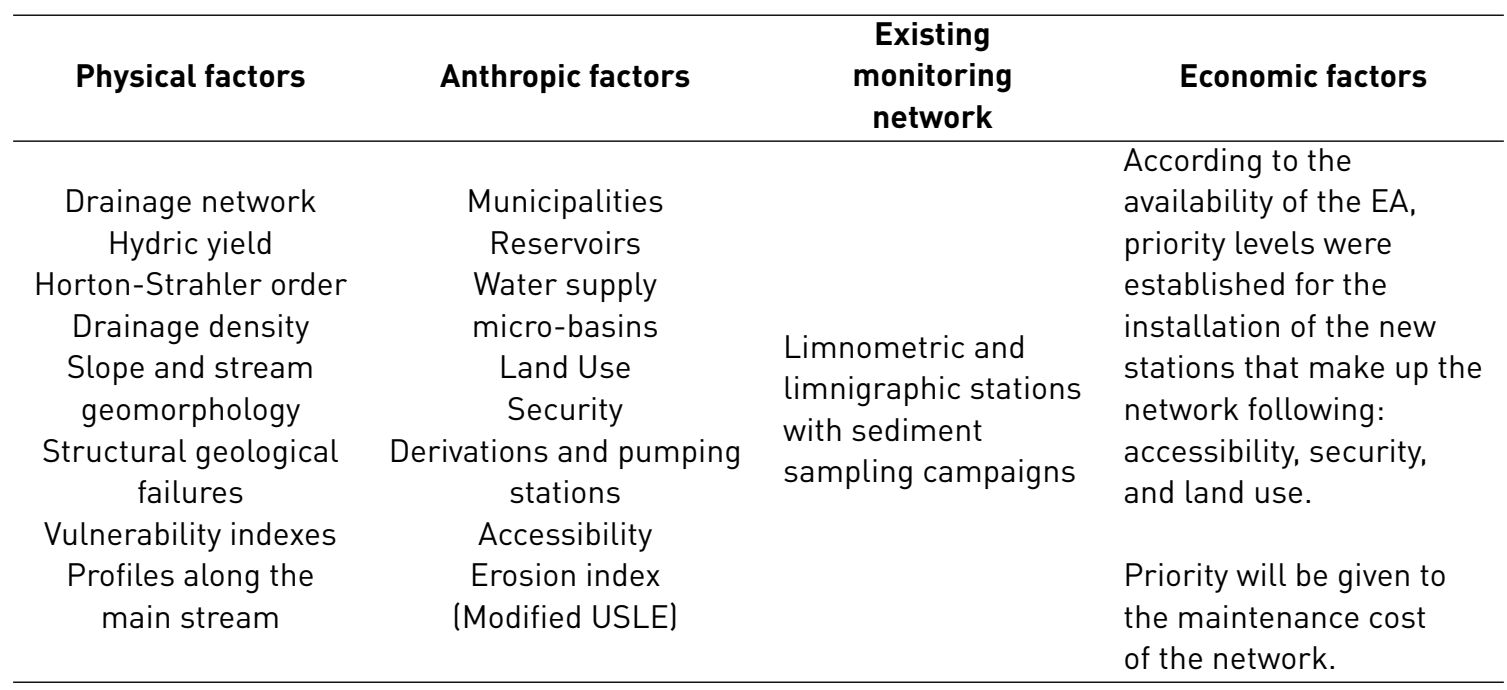

Source: Adapted from [23].

transport monitoring networks.

The criteria for all monitoring networks must be defined by experts or individuals with knowledge of the region to provide coherence and validity to the procedure. These values and expert criteria are revealed in the results chapter.

Initially, the same weight factor is given to all maps. After merging the maps, sites where points are close enough, new water monitoring stations are uncovered. It is important to highlight that those sites where quantity, quality, and sediment values are sufficiently close, it is mandatory to propose a new monitoring station with these variables (water, quality, and sediment).

The information gathered from monitoring networks helps to prioritize the macro-location of stations in order to reduce predefined issues to be tackled, and to choose the areas on which to ensure optimal water-resource management.

The main expert criteria for the water quantity monitoring networks were the following:

The physical factors that influence new monitoring stations or points of interest are presented in those sub-basins where: a high quartile of water is yielded, annual precipitation is over $4,000 \mathrm{~mm}$, the Horton-Strahler order is over five, there is high-drainage density, step reaches defined as cascades are capable of sediment transport [28], there is a very low water regulation index, a very high water use index, very high vulnerability indices, or a high aridity index.
Criteria for anthropic factors to include for possible monitoring stations were as follows: proximity to municipalities or populated zones, locations upstream or downstream from reservoirs, proximity to water supply micro-basins, agricultural irrigation zones where it is necessary to measure captured water and remaining water in the river, derivation sites and pumping stations in charge of receiving/transferring water to other basins, or a high water use index. All sites must have adequate access to the river in order to guarantee data capture. Also, security is an important factor to avoid delinquency and robbery.

It is mandatory to check existing monitoring stations to confirm the needs of each one according to the terms indicated in the methodology. The goal is to continue with the capture of historical data from existing limnigraphic stations. Therefore, these stations must be retained in the redesigned monitoring network, and limnometric stations must be converted to limnigraphic stations.

The economic factor is defined in accordance with CORNARE's budget availability giving priority to the maintenance cost of the redesigned network. Different priority levels will be established for new station installation, which defines the network's aspects, as mentioned above, and prioritizes the update of existing stations, accessibility, security, and land use.

\section{Results and discussion}

This section indicates the main results, following the application of the proposed methodology. 


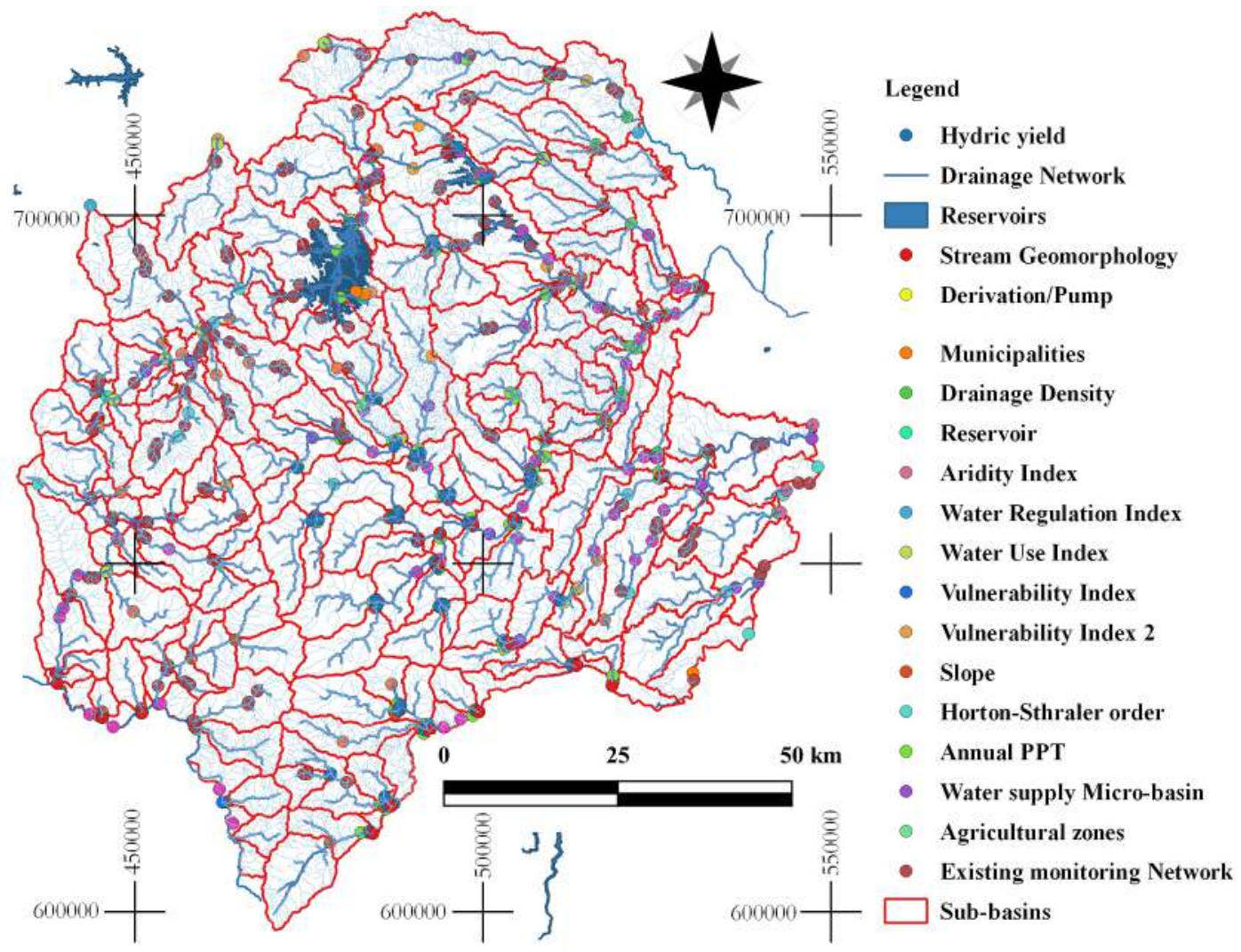

Figure 3 Points of interest for hydrometric monitoring

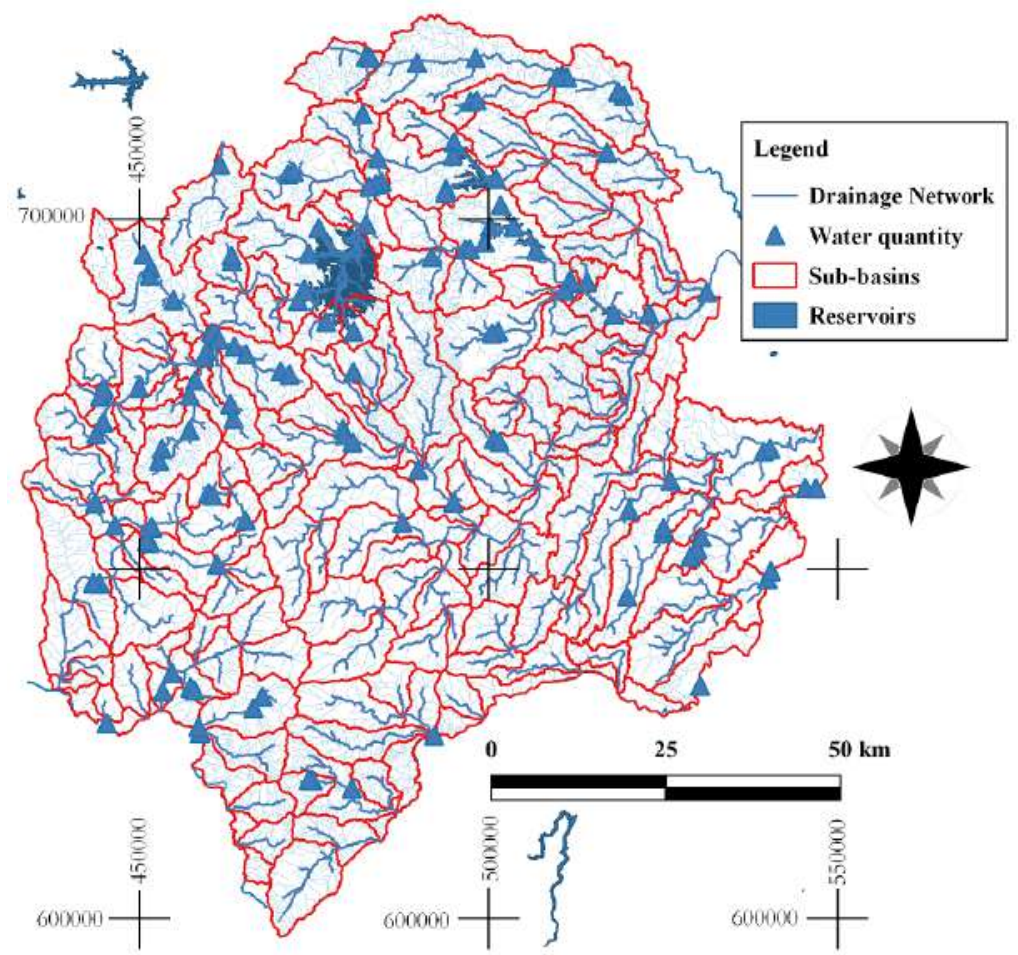

Figure 4 Proposed water-quantity monitoring network, blue triangles indicate the macro-location of preliminary stations 


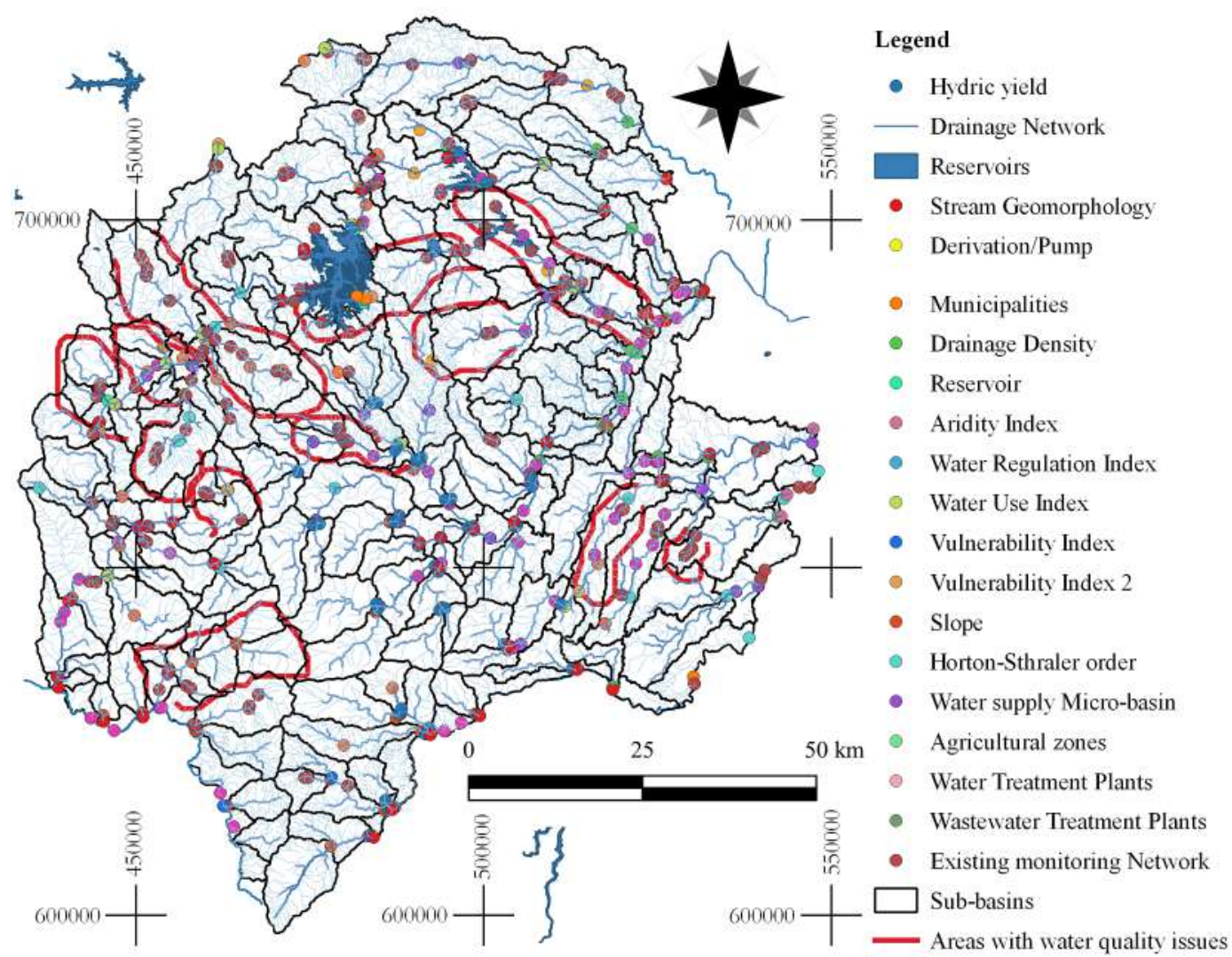

Figure 5 Points of interest for the water-quality monitoring network. Red continuous lines are previously identified areas with water quality issues, which had to be included in the analysis

Figure 3 shows the points of interest for hydrometric monitoring which correspond to selected sites that meet the above-mentioned criteria for the water-quantity monitoring network.

Then, the selection of monitoring sites is performed by using a proximity method such as weight distance is used, where the stations which are close enough are merged into a single station in order to reduce redundancy. Figure 4 shows the final proposal for the water-quantity monitoring network.

The main expert criteria for water quality and hydro-biological monitoring networks were the following: The physical factors that influence the new monitoring stations, or points of interest, are presented in those sub-basins where: confluence of two main currents is performed, the Horton-Strahler order is over five, there is high drainage density, step reaches are defined as cascades capable of sediment transport, there is a very low water regulation index, very high vulnerabilities indices, or a high aridity index.

Criteria for anthropic factors to include for monitoring stations were: two sites per municipality or populated zone (before and after), that they be upstream and downstream of reservoirs, water supply micro-basins, agricultural irrigation and industrial and agricultural discharges where it is necessary to measure captured water and remaining water in the river, derivation sites and pumping stations in charge of receiving/transferring water to other basins, or a high water use index. All sites must have good accessibility to the river to guarantee data capture. Also, security is an important factor in order to avoid delinquency and robbery.

It is mandatory to check existing monitoring stations to confirm the need of each station according to the terms indicated in the methodology. The goal is to continue with the capture of historical data from existing stations. Therefore, stations must be retained in the redesigned monitoring network.

The economic factor was defined in accordance with the budget availability of CORNARE, and priority was given to the cost of maintenance for the redesigned network. Various levels were established for the installation of the new stations in the network as defined by aspects mentioned above. These prioritize accessibility, security, and land use. 


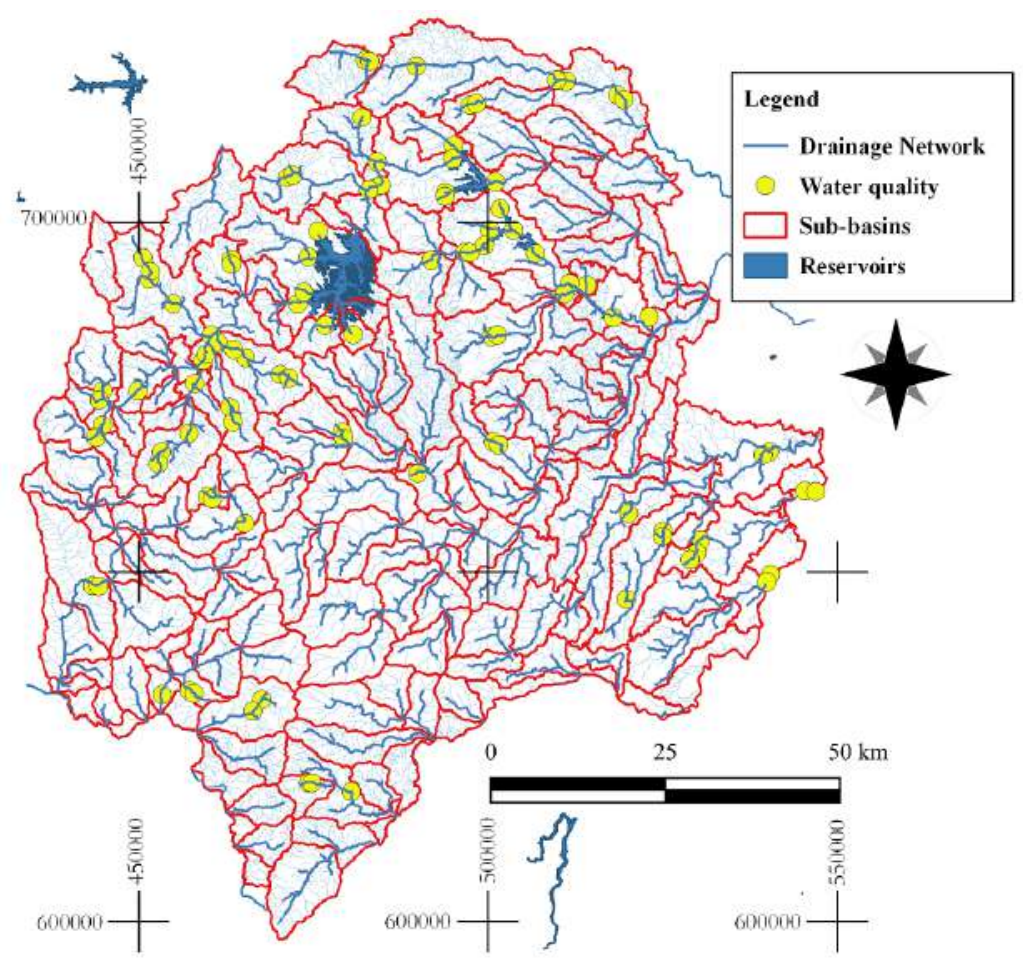

Figure 6 Proposed water-quality monitoring network, yellow circles indicate the macro-locations of preliminary stations

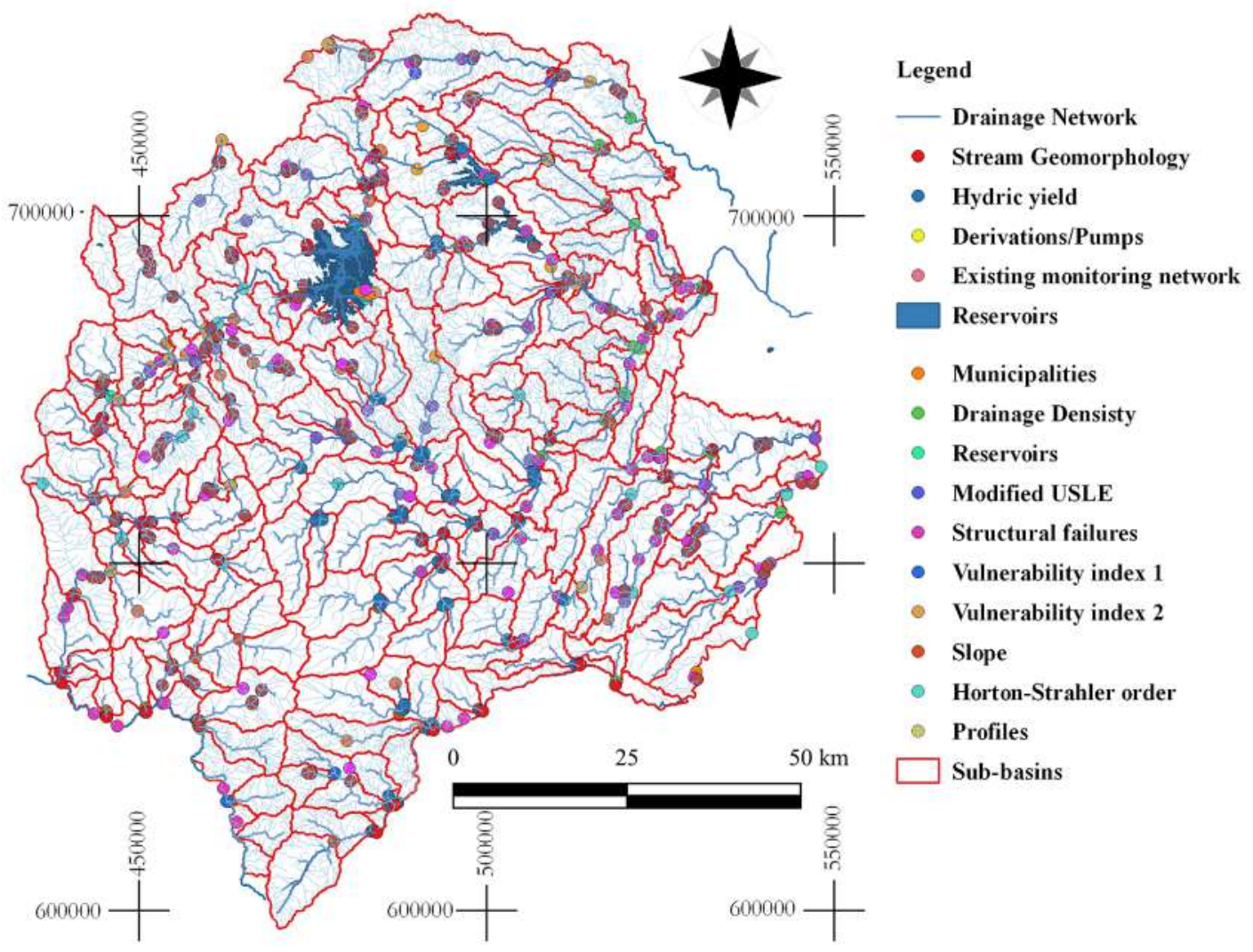

Figure 7 Points of interest for the sediment-transport monitoring network 


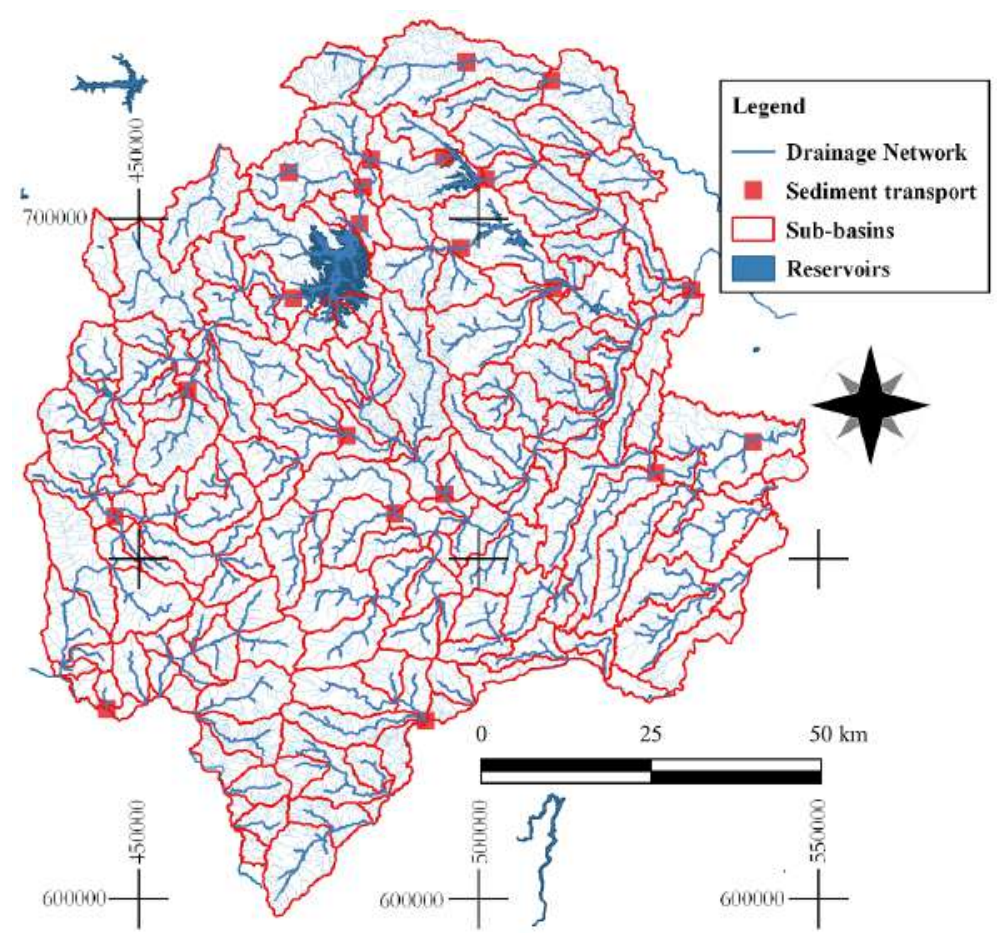

Figure 8 Proposed sediment-transport monitoring network, red squares indicate the macro-locations of preliminary stations

Figure 5 shows the points of interest for quality and hydro-biological monitoring that correspond to selected sites which meet the criteria described above. The red lines are areas identified during the fieldwork, where water quality must be monitored in the network, owing to the problems identified.

Then, monitoring site selection is performed by using the proximity method, where those stations which are sufficiently close to each other are merged to create a single station in order to reduce redundancy. Figure 6 shows the final proposal for the water-quality and hydro-biologic monitoring network.

The main expert criteria for the sediment transport monitoring networks were the following:

The physical factors that influence new monitoring stations, or points of interest, are presented in those sub-basins where: there is a confluence of two main currents, there is a high quartile of water yielded, the Horton-Strahler order is over five, there is high drainage density, step reaches defined as cascades are capable of sediment transport, geological structural failures cross the river, or very high vulnerability indices are present.

The profiles along the main stream are very important because they allow the identification of tectonic failure crossing points with the bed channel, and also that of places where a strong change in longitudinal slope is present. These sites are points of interest.

Criteria for anthropic factors to include monitoring stations were: proximity to municipalities or populated zones, placement upstream or downstream of reservoirs, water supply micro-basins, or derivations sites and pumping stations in charge of receiving/transferring water to other sub-basins, all sites must have adequate access to the river to guarantee data and sample capture. Also, security is an important factor to avoid delinquency and robbery.

It is mandatory to check existing monitoring stations to confirm the need of each station, in the terms indicated in the methodology. The goal is to continue with the capture of historical data from existing stations. Therefore, these stations must be retained in the redesigned monitoring network.

The economic factor was defined in accordance with the budget availability of CORNARE. Priority was given to the maintenance cost of the redesigned network, where different levels were established for the installation of the new stations that define the aforementioned network aspects. Accessibility, security and land use were prioritized.

Figure 7 shows the points of interest for the sediment transport monitoring networks that correspond to selected sites, which meet the criteria listed above. 


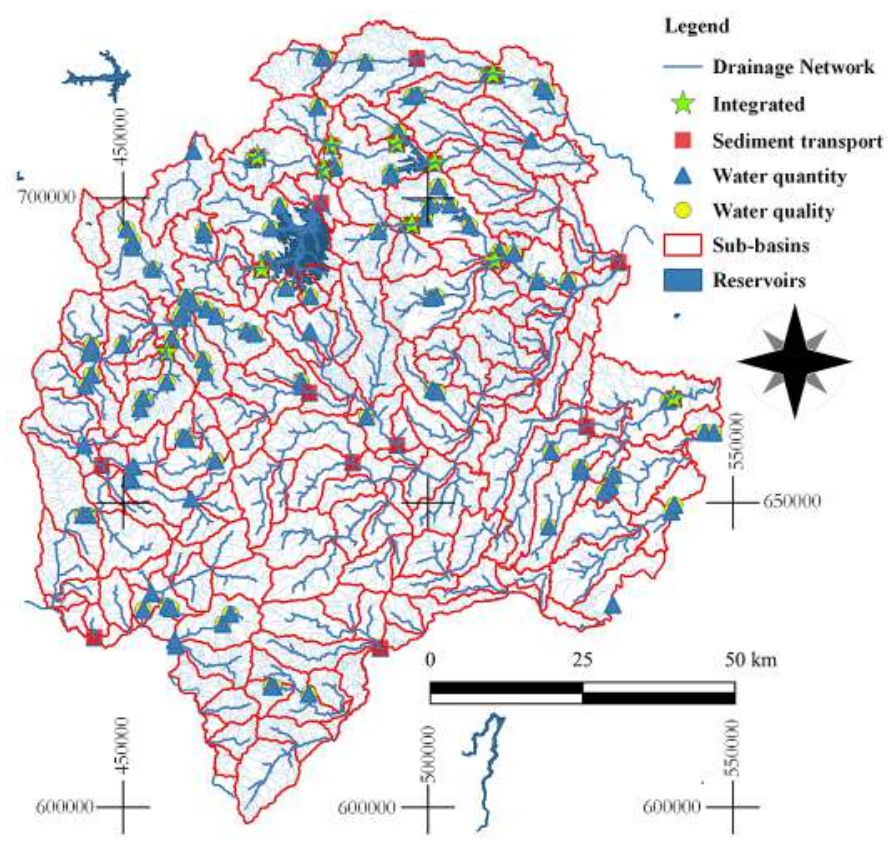

Figure 9 Proposed hydrological monitoring network, blue triangles for water quantity stations, yellow circles for quality stations, red squares for sediment, and green star points are integrated stations (all components)

Then, the selection of monitoring sites is performed by using a proximity method, applying a simple weight distance method where those stations close enough are merged into a single station to reduce redundancy. Figure 8 shows the final proposal for the water-sediment transport monitoring network.

Finally, all stations were integrated onto one map, as shown in Figure 9. To show the proposed water quantity, quality, and sediment monitoring network, some stations monitor all components, called as integrated stations, as specified by the mandatory and priority criteria for new station installation. The number of monitoring points was increased to cover unmonitored variables and missing spots within the CORNARE region, the macro-location of each station was proposed therein. Therefore, the goal was achieved, as monitoring site coverage lquantity, quality, and sediment) was improved to better attend to water resource management and planning requirements, using secondary available information.

Colombian authorities, such as IDEAM only measure suspended loads. However, the idea is to include bed and saltation loads in future monitoring. Sediment monitoring sites are not a priority in Colombia because they are expensive, and measurement during sediment-transporting events is complex, as the most significant runoff events are of short duration. However, this is a viable opportunity for the future to tackle problems such as an insufficient number of monitoring sites, very limited data, and differences in measurement methodology. However, the process, analysis, and interpretation of the existing sediment database enabled the understanding of some basic characteristics of sediment transport for different purposes, such as mining, water pollution, deforestation, and aquatic ecosystem maintenance.

Exploring different optimization techniques may be an appropriate extension of this study. More complex methods could be applied to optimize the macro-location of monitoring sites, by modifying the weight distance methods.

The proposed methodology is useful and straightforward to apply to those places where a redesign is required, as the monitoring network has not been updated and monitoring station macro-locations do not properly encompass the territory, due to lack of planning and management. In this sense, said method requires available data, as related to the physical and anthropic characteristics of the region, in order to capture the main characteristics of quantity, quality, and sediment in the water for management and planning purposes. This approach includes a new paradigm, which involves integrated monitoring sites, where quantity, quality, hydro-biological, and sediment monitoring may be performed simultaneously. 


\section{Conclusions recommendations}

This redesign is relevant in order to improve the spatial distribution of the monitoring networks to capture data and to help to decision-makers to respond to different water resources planning and management issues, as other technical and environmental problems in tropical regions.

The proposed methodology, with different strategies for quantity, quality, and hydro-biologic and sediment transport networks was proposed and applied in a complex tropical region in Colombia, with satisfactory results to obtain the macro-location of monitoring stations. The use of secondary information, combined with GIS tools, could be applied in other sites where the lack of historical data is also detected.

Although the redesign of surface hydrological monitoring networks requires historical data for the use of more complex techniques, such as entropy and optimization strategies, this simple technique has proven to be adequate for tropical Andean watersheds, including those in the CORNARE region, and could be applied by other Environmental Agencies, in Colombia, with similar information.

The proposed approach and technique to integrate water quantity, quality, and sediment-monitoring network in the redesign of hydrological monitoring networks, where physical factors, anthropic factors, existing monitoring network and economic factors are the key points of the proposed methodology, can be considered as one of the main results of this research.

This investigation was focused on surface water. However, wetlands and groundwater are beyond the scope of this investigation despite the interconnection between surface and underground water. Therefore, these results must be integrated into the quantity and quality of future underground water networks, so that surface-underground water interactions can be included and investigated.

\section{Declaration of competing interest}

None declared under financial, professional and personal competing interests.

\section{Acknowledgements}

This research project was financed by the Environmental Agency, "Corporación Autónoma Regional de las cuencas de los ríos Negro y Nare, CORNARE". Project 281-2013, entitled "Avanzar en el conocimiento del recurso hídrico superficial para la conservación de los ecosistemas de la región".

\section{References}

[1] M. L. Erwin and P. A. Hamilton. (2005, May) Monitoring our rivers and streams. [USGS sciencia for a changing world]. Accessed Nov. 12, 2018. [Online]. Available: https://pubs.usgs.gov/fs/fs-077-02/

[2] T. H. Nguyen, B. Helm, H. Hettiarachchi, S. Caucci, and P. Krebs, "The selection of design methods for river water quality monitoring networks: a review," Environm. Earth Sciences, vol. 78, no. 3, February 2019. [Online]. Available: https://doi.org/10.1007/s12665-019-8110-x

[3] S. Park, J. Choi, S. Wang, and S. Park, "Design of a water quality monitoring network in a large river system using the genetic algorithm," Ecological Modelling, vol. 199, no. 3, December 12006. [Online]. Available: https://doi.org/10.1016/j.ecolmodel.2006.06.002

[4] R. 0. Strobl and P. D. Robillard, "Network design for water quality monitoring of surface freshwaters: A review," Journal of Environmental Management, vol. 87, no. 4, June 2008. [Online]. Available: https://doi.org/10.1016/j.jenvman.2007.03.001

[5] J. Keum, K. C. Kornelsen, J. M. Leach, and P. Coulibaly, "Entropy applications to water monitoring network design: A review," Entropy, vol. 19, no. 11, November 2017. [Online]. Available: https://doi.org/10.3390/e19110613

[6] J. C. Bastidas, J. Vélez, J. Zambrano, and A. Londoño, “Design of water quality monitoring networks with two information scenarios in tropical Andean basins," Environ. Sci. Pollut. Res., vol. 24, no. 25, September 2017. [Online]. Available: https://doi.org/10. 1007/s11356-017-9021-6

[7] W. Nomquphu, E. Braune, and S. Mitchell, "The changing water resources monitoringenvironment in South Africa," South African Journal of Science, vol. 103, pp. 306-310, Jul. 2007.

[8] I. T. Telci, K. Nam, J. Guan, and M. M. Aral, "Optimal water quality monitoring network design for river systems," Journal of Environmental Management, vol. 90, no. 10, July 2009. [Online]. Available: https://doi.org/10.1016/j.jenvman.2009.04.011

[9] EPA United States Enviromental Protection Agency. (2003, March) Elements of a state water monitoring and assessment program. [EPA United States Enviromental Protection Agency]. Accessed Nov. 10, 2018. [Online]. Available: https://bit.ly/33QQmol

[10] C. Borden and D. Roy. (2015, Sep) Water quality monitoring system design. IISD International Institute for Sustainable Development. [Online]. Available: https://bit.ly/2JdfKgA

[11] World Meteorological Organization. (2009) Guide to hydrological practices, Volume IImanagement of water resources and application of hydrological practices. [World Meteorological Organization]. [Online]. Available: https://bit.ly/2JdRpaC

[12] M. Babić and et al, "Establishment of the sediment monitoring system for the sava river basin," Water Research and Management, vol. 5, no. 4, pp. 3-14, Jan. 2015.

[13] J. Bogen, D. E. Walling, and T. J. Day, Eds., Erosion and sediment transport monitoring programmes in river basins : proceedings of the International Symposium held at Oslo, Norway, 24-28 August 1992, ser. IAHS Proceedings \& Reports. Wallingford, UK: International Association of Hydrological Sciences, 1992.

[14] W. Salomons and J. Brils, "Contaminated sediments in european river basins," European Sediment research Network (SedNet), Tech. Rep. EVK1-CT-2001-20002, Sep. 2004. 
[15] Y. Xiaoqing. (2003) Manual on sediment management and measurement. [WMO World Meteorological Organization]. [Online]. Available: https://bit.ly/2pHwt4Q

[16] L. Posada, Transporte de sedimentos, 1st ed. Medellín, Col: Universidad Nacional de Colombia, 1994.

[17] EPA United States Enviromental Protection Agency. (2018) Integrated assessment of healthy watersheds. [EPA United States Enviromental Protection Agency]. Accessed Nov. 15, 2018. [Online]. Available: https://bit.ly/35YUGEc

[18] A. Borja and et al, "The water framework directive: Water alone, or in association with sediment and biota, in determining quality standards?" Marine Pollution Bulletin, vol. 49, no. 1, August 2004. [Online]. Available: https://doi.org/10.1016/j.marpolbul.2004.04.008

[19] J. Brils, "Sediment monitoring and the European Water Framework Directive," Ann Ist Super Sanita, vol. 44, no. 3, pp. 218-23, feb.

[20] Ministerio de Ambiente, Vivienda y Desarrollo Territorial. (2010) Política Nacional para la Gestión Integral del Recurso Hídrico. [Ministerio de Ambiente, Vivienda y Desarrollo Territorial]. [Online]. Available: https://bit.ly/2Pcxwoa

[21] D. Shepard, "A two-dimensional interpolation function for irregularly-spaced data," in Proceedings of the 1968 23rd ACM national conference, New York, NY, 1968, pp. 517-524.

[22] Q. Chen, W. Wu, K. Blanckaert, J. Ma, and G. Huang, “Optimization of water quality monitoring network in a large river by combining measurements, a numerical model and matter-element analyses," J. Environ. Manag., vol. 110, November 15 2012. [Online]. Available: https://doi.org/10.1016/j.jenvman.2012.05.024
[23] A. Londoño and J. Vélez, “Avanzar en el conocimiento del recurso hídrico superficial para la conservación de los ecosistemas de la región, a través del convenio interadministrativo 281-2013 con la Universidad Nacional, mediante la mutua cooperación, pero guardando la independencia que le es propia a cada una de las entidades," Universidad Nacional de Colombia, Medellín, Col, Tech. Rep., Jan. 2016.

[24] G. Poveda, "La Hidroclimatología de Colombia: Una síntesis desde la escala interdecadal hasta la escala diurna," Revista Academia Colombiana de Ciencias, vol. 28, no. 107, pp. 201-222, Jan. 2004.

[25] G. Poveda, P. Waylen, and R. Pulwarty, "Annual and inter-annual variability of the present climate in northern South America and southern Mesoamerica," Palaeogeography, Palaeoclimatology, Palaeoecology, vol. 110, no. 1, May 3 2006. [Online]. Available: https://doi.org/10.1016/j.palaeo.2005.10.031

[26] IDEAM. (2015) Estudio nacional del agua 2014. [IDEAM, MINAMBIENTE]. [Online]. Available: https://bit.ly/1TrRtPc

[27] J. M. Bedoya, G. Poveda, K. E. Trenberth, and J. J. Vélez, “Interannual hydroclimatic variability and the 2009-2011 extreme ENSO phases in Colombia: from Andean glaciers to Caribbean lowlands," Theoretical and Applied Climatology, vol. 135, no. 3, February 2019. [Online]. Available: https://doi.org/10.1007/s00704-018-2452-2

[28] M. A. Jiménez, "Morphological representation of drainage networks, implications on solute transport and distributed simulation at the basin scale," M.S. thesis, Universidad Nacional de Colombia, Medellín, Colombia, 2015. 